\title{
Covid-19 Pandemi Sürecinde Spor Yapan Bireylerin Serbest Zaman Motivasyonlarının İncelenmesi
}

\author{
Burak GÜRER ${ }^{1 *}$ \\ ${ }^{1}$ Gaziantep Üniversitesi, Spor Bilimleri Fakültesi, Gaziantep.
}

Orijinal Makale

Gönderi Tarihi: 10.03.2021
Kabul Tarihi: 23.04.2021
DOI: $10.25307 /$ jssr.894818

Online Yayın Tarihi: 30.06.2021

\section{Öz}

Bu çalışmada, Covid-19 pandemi sürecinde rekreatif olarak spor yapan bireylerin serbest zaman motivasyonları ve bu süreçte hangi sporlara yöneldiklerinin incelenmesi amaçlanmıştır. Bu amaçla Pelletier ve ark., (1991) tarafından geliştirilen, ilk kez Mutlu (2008) tarafından daha sonra Güngörmüş (2012) tarafından geçerlik güvenirlik çalışması yapılarak Türkçe'ye uyarlanan "Serbest Zaman Motivasyon Ölçeği" veri toplama aracı olarak kullanılmıştır. Araştırmada rastgele örneklem yöntemi ile seçilmiş 291 (138 kadın, 153 erkek) sporcu katılmıştır. Verilerin analizinde Independent Samples t test ve Tek yönlü (One way) Anova testi kullanılmıştır. Gruplar arası farklılığı ortaya koymak için Post Hoc LSD testi yapılmıştır. Araştırma bulgularına göre yaş, cinsiyet, sporcu lisansı ve yapılan spor branșı değişkenlerine göre istatistiksel olarak anlamlı bir fark bulunamamıştır. Eğitim durumu değişkeninde motivasyonsuzluk alt boyutunda istatistiksel olarak anlamlı bir sonuca rastlanmıştır. Sonuçta lisans mezunlarının serbest zaman etkinliklerinde motivasyon seviyelerinin düşük olduğu sonucuna varılmıştır. Ayrıca daha çok doğa sporu etkinliklerine ve bireysel sporlara yönelim olduğu sonucuna varılmıştır.

Anahtar kelimeler: Covid-19, Serbest zaman motivasyonu, Spor.

\section{Investigation of Leisure Motivations of Sports Participants During the Covid-19 Pandemic Process}

\begin{abstract}
In this study, it was aimed to examine the leisure motivations of individuals who participated in sports recreational during the Covid-19 pandemic and which sports they engaged to in this process. For this purpose, "Leisure Time Motivation Scale" developed by Pelletier et al. (1991), first adapted to Turkish by Mutlu (2008) and second by Güngörmüş (2012), was used as a data collection tool. 291 (138 women, 153 men) athletes selected by random sampling method participated in our study. Independent Samples t test and One-way Anova test were used to analyze the data. Post Hoc LSD test was used to reveal the difference between groups. According to the findings of the study, no statistically significant difference was found in terms of age, gender, athlete license and sports branch variables. The statistically significant result was found in the lack of motivation subscale in the educational status variable. As a result, it was concluded that undergraduate graduates have low motivation levels in leisure time activities. In addition, it was concluded that there was a tendency towards nature sports activities and individual sports.

Keywords: Covid-19, Leisure motivation, Sports.
\end{abstract}

\footnotetext{
* Sorumlu yazar: Doç. Dr. Burak GÜRER, E-posta: burakgurer27@ gmail.com
} 
Gürer, B. (2021). Covid-19 pandemi sürecinde spor yapan bireylerin serbest zaman motivasyonlarının incelenmesi. Spor Bilimleri Araştırmaları Dergisi, 6(1), 24-35.

\section{GíRiş}

SARS-CoV-2'nin sebep olduğu COVID-19 pandemi tehdidi, sağlık, ekonomi ve yaşam tarzı açısından insan toplumu için yıkıcı bir durum olarak ortaya çıkmaktadır (Woods vd., 2020). 8 Nisan 2021 tarihi itibariyle Covid-19 sebebi ile 2.880.726 ölüm, 132.730.691 doğrulanmış COVID-19 vakası bulunmaktadır (WHO, 2021). Covid-19 pandemisi, dünya çapında birçok insanı evde kalmaya ve bir süre kendi kendine izole etmeye zorlamıştır (Hammami, Harrabi, Mohr ve Krustrup, 2020). Covid-19 sürecinde, ev temelli etkinliklere geçiş, online sunum ve kullanımın yaygınlaşması, bağlantı kurma ihtiyacının artması, artan psikolojik destek talebi ve başkalarına yardım etme ve gönüllülük konusunda sorunlar ortaya çıkmıştır (Sivan, 2020). Bu süreçle bağlantılı olarak bazı çalışmalarda, karantina sırasında izole edilmenin olumsuz psikolojik etkileri, değerlendirilmiş olup (Brooks vd., 2020) travma sonrası stres semptomları; kafa karışıklığı, öfke, duygusal rahatsızlık, depresyon, stres, olumsuz ruh hali, sinirlilik, uykusuzluk, kaygı ve sinirlilik durumu olarak ortaya çıkmıştır (Kluge, 2020).

Farklı bir açıdan bakılırsa günlük hayatın yavaşlaması, fiziksel hareketliliğin azlığı ve sürekli stres altında yaşamak gibi olumsuz etkiler beslenme bozuklarının oluşmasına da sebebiyet vermiştir. Bir başka olumsuz etki olarak, insanların çoğu ev ortamında yemek yeme eğilimindedir. Evde kalan kişiler uzun ya da kısa süre TV izlemekte olup ve sık sık atıştırmalık yeme durumu ortaya çıkmıştır (Thomson, Spence, Raine ve Laing, 2008). Covid-19 nedeniyle benzeri görülmemiş hareketlilik kısıtlamaları başlamış olup, macera seyahati ve turizm endüstrisi durmuştur. $\mathrm{Bu}$ kısıtlamalar, bir yandan da birçok kişiye macera seyahatinin felsefesini ve uygulamasını yeniden planlama imkanı sağlamıştır. Yakın bir bölgedeki doğa ortamında insan sayısının az, karbon seviyesinin düşük olduğu macera alanları hem mevcut pandemi sürecinde hem de pandemi sonrası koşullar için cazip bir alternatif olmaya başlamıştır (Mackenzie ve Goodnow, 2020). Özgürlüğün çok az olduğunu ya da hiç olmadığını algılayan bireyler, serbest zaman faaliyetlerinde memnuniyetsizlik yaşayabilirler (Ellis ve Witt, 1986). Covid-19 pandemi sürecinde yapılan araştırmalar, karantina altında yapılan düzenli egzersizlerin dayanıklılık ve duygulara pozitif etki ettiği, depresif duyguları azalttığını göstermiştir (Carriedo, Cecchini, Fernandez-Rio ve Méndez-Giménez, 2020). Virüsün etkisini azaltmak ve süreci en az hasarla atlatmak için rekreasyonel etkinliklere başvurulması fayda sağlayacaktır (Güzel, Yıldız, Esentaş ve Zerengök, 2020).

Tutumlar, inançlar, değerler ve kişilik, bireyleri farklı kılan özellikler olup bir faaliyete girdiklerinde motivasyonlarını oluşturan temel nedenleri meydana getirmektedir (Chelladurai, 2006). Motivasyon, bir faaliyet yapmak için ilham almakla ilgilidir (Bang ve Ross, 2009; Kim, 2018). Serbest zaman, meslek, günlük ev işleri ve günlük rutin işler gibi zorunluluklar dışında olan zaman içinde meydana gelen isteğe bağlı faaliyetleri içerir. Kişisel tercihlere dayalı olarak geniş ölçüde farklı faaliyetler serbest zaman olarak değerlendirilebilir (Iso-Ahola, 1980). Bir tanıma göre serbest zaman, "televizyon izlemekten futbol oynamaya, arkadaşlarla bara gitmeye, izci lideri olarak gönüllü olmaya" kadar uzanan her şeyi içeren geniş bir kavramdır (Bedford, Burningham, Cooper, Green ve Jackson, 2011). İnsanların hayatlarından mutlu olmaları elde ettikleri yaşam kalitelerine bağlı olarak gelişecektir (Tütüncü, 2012). Psikolojik ve fiziksel sağlık, kişisel tatmine katkıda bulunan ana faktörlerdir ve bir kişinin yaşam kalitesini tanımlamaya yardımcı olmaktadır (Iso-Ahola ve Wessinger, 1984). Serbest zamanın faydaları, yapılan serbest zaman etkinlikleri sırasında katılımcıların yaşadığı olumlu etkiler olarak tanımlanmıştır (Driver, 1990). 
Serbest zamanın faydaları öznel bir kavramdır ve kişisel deneyimlerle ilgilidir (Kao, 1995). Serbest zaman sürecinde kazanılan deneyimler, insanların zihinsel ve fiziksel sağlıklarını iyileştirmelerine, fiziksel ve zihinsel ihtiyaçlarını karşılamalarına yardımcı olmaktadır (Chen, 2001). Serbest zaman faaliyetlerine katılmanın faydaları oldukça fazladır. Aktivitelere katılan bireyler psikolojik, fizyolojik, eğitimsel, sosyal ve rahatlama açısından fayda sağlarlar. Bunun dışında yorgunluk, kaygı ve iş stresini azaltmaktadır (Soyer vd., 2017).

Çalışmamızda odak noktayı oluşturan serbest zaman sporu sağlık açısından fazla miktarda yarar sağlamaktadır. Düzenli ve sık yapılan sporun her yaştan bireyde bağışıklığı güçlendirdiği ve enfeksiyonlardan koruduğu bilinmektedir (Campbell ve Turner, 2018). Spor, genel kardiyovasküler risklerin azaltılmasına katkıda bulunur (Hegde ve Solomon, 2015). Pandemi sürecinde sporun oynadığı rol, eşi görülmemiş, büyüleyici ve sporun hayatımızın her alanında sahip olduğu muazzam etkiyi ortaya koymaktadır (Gilat ve Cole, 2020). Böylelikle sporun, bu süreç içinde bir serbest zaman etkinliği olarak üstlenmiş olduğu görevin önemi daha iyi anlaşılmaktadır. Bu araştırmada, tüm dünyayı etkisi altına alan Covid-19 pandemi sürecinde eve kapanmak zorunda olan ve birçok kısıtlamayla karşılaşmış bireylerin serbest zaman motivasyonları ve daha çok hangi etkinliklere yöneldiğinin ortaya konması amaçlanmıştır.

\section{YÖNTEM}

\section{Araştırma Modeli}

$\mathrm{Bu}$ araştırma, nicel araştırma yöntemlerinden betimsel tarama modelinde tasarlanmış olup veri toplama aracı olarak anket tekniği kullanılmıştır.

\section{Evren ve Örneklem}

Araştırmanın evrenini Gaziantep ilinde serbest zaman etkinliği olarak spor yapanlar, örneklemini ise rastgele örneklem yöntemi ile seçilmiş serbest zamanlarında farklı sporları yapan bireyler oluşturmuştur. Araştırmaya 291 (138 kadın, 153 erkek) sporcu katılmıştır.

\section{Veri Toplama Aracı}

Veri toplama aracı olarak kişisel bilgi formu ve Serbest Zaman Motivasyon Ölçeği kullanılmıştır. Kişisel bilgilerin toplanması amacı ile araştırmacı tarafından oluşturulan cinsiyet, yaş, eğitim durumu, branş gibi bilgilerin yer aldığı kişisel bilgi formu kullanılmıştır. Veriler Pelletier, Vallerand, Blais ve Brière (1991) tarafından geliştirilmiş olan, Mutlu (2008) ve daha sonra Güngörmüş (2012) tarafından geçerlik güvenirlik çalışması yapılarak Türkçe'ye uyarlanan "Serbest Zaman Motivasyon Ölçeği” kullanılarak toplanmıştır. Ölçeğin orijinali, "bilmek" (içsel motivasyon), "başarmak" (içsel motivasyon), "uyarılmak" (içsel motivasyon), "belirlemek" (dışsal motivasyon), "belirlemek" (dışsal motivasyon), "dışsal düzen” (dışsal motivasyon) ve "motivasyonsuzluk" gibi 7 alt boyut ve toplam 28 maddeden oluşmakta ve katılımcıların rekreasyona katılıma motive edebilecek ve onların motivasyonlarını etkileyebilecek faktörleri içermektedir. Ölçekte yer alan ifadeler "Hiç Katılmıyorum (1)" ve "Tamamen Katılıyorum (5)" şeklinde beşli Likert tipi ölçektir. Anketin Türkçe versiyonunun güvenirlik ve geçerlik testi için yapılan faktör analizi sonucuna göre, orijinal ankette yer alan 6 ifade faktör yükleri .40'ın altında olduğu için anketin Türkçe versiyonundan çıkarılmıştır. Anketin Türkçe versiyonu toplam 22 maddeden ve 5 alt boyuttan oluşmaktadır. Anketin toplam iç tutarlılık katsayısı ise .77'dir (Mutlu, 2008). Ölçek alt boyutları; Bilmek ve Başarmak: 6., 9., 
13., 16., 20. ve 27. Maddeler, Uyaran yaşama: 11., 18. ve 25. Maddeler, Özdeşim/İçe atım: 10., 14., 17., 21., 24. ve 28. Maddeler, Dişsal düzenleme: 1., 8., 15. ve 22. Maddeler, Motivasyonsuzluk: 5., 12. ve 19. maddelerdir.

\section{Araş̧ırma Yayın Etiği}

Araştırma için Gaziantep Üniversitesi Sosyal ve Beşeri Bilimler Etik Kurulu'ndan 2021/04 karar numaralı ve 27.01.2021 tarihli onay alınmıştır.

\section{Verilerin Toplanması}

Veriler araştırmacı tarafından Sağlık Bakanlığı tarafınca Covid-19 tedbirlerine uygun olarak yüz yüze toplanmıştır. Ölçek katılımcılara değişik bölgelerde yer alan parklarda spor yaparken uygulanmıştır. Her ölçek katılımcılardan alınırken dezenfektan ile el temizliği yapılmıştır. Toplanan anketler bir hafta kimsenin girmediği bir odada bekletildikten sonra istatistiksel analiz için değerlendirmeye alınmıştır.

\section{Verilerin Analizi}

Verilerin analizinde SPSS 22.0 istatistik programı kullanılmıştır. Yapılan normallik dağılımı analizinde Skewness ve Kurtosis değerlerine bakılmış ve verilerin normal dağılım gösterdiği görülmüştür. Bundan sonra verilerin analizinde Independent Samples t test ve Tek yönlü (One way) Anova testi kullanılmıştır. Gruplar arası farklılığı ortaya koymak için Post Hoc LSD testi yapılmıştır. Verilerin Cronbach alpha güvenirlik katsayısı .64 olarak bulunmuştur.

\section{BULGULAR}

Araştırmanın bu bölümünde istatistiksel analizler neticesinde elde edilen analiz sonuçlarına ve yorumlarına yer verilmiştir.

Tablo 1. Serbest zaman motivasyon değerlerinin cinsiyet değişkenine göre dağılımları

\begin{tabular}{lcccccc}
\hline & Cinsiyet & $\mathbf{N}$ & Ort. $(\overline{\mathbf{x}})$ & $\mathbf{S}$ & $\mathbf{t}$ & p \\
\hline \multirow{2}{*}{ Bilmek ve Başarmak } & Erkek & 153 & 3,94 &, 57 &,- 587 & \multirow{2}{*}{, 558} \\
& Kadın & 138 & 3,98 &, 62 & & \\
Uyaran Yaşama & Erkek & 153 & 3,84 &, 85 & $-1,302$ & \multirow{2}{*}{, 194} \\
\multirow{2}{*}{ Özdeşim/İçe Atım } & Kadın & 138 & 3,97 &, 76 & & \\
\multirow{2}{*}{ Dışsal Düzenleme } & Erkek & 153 & 3,86 &, 48 &, 102 & \multirow{2}{*}{, 919} \\
& Kadın & 138 & 3,85 &, 55 & & \\
\multirow{2}{*}{ Motivasyonsuzluk } & Erkek & 153 & 2,75 &, 73 & \multirow{2}{*}{, 511} & \multirow{2}{*}{, 511} \\
& Kadın & 138 & 2,70 &, 74 & & \multirow{2}{*}{, 729} \\
\hline
\end{tabular}

Serbest zaman motivasyonları değerleri cinsiyet değişkenine göre incelendiğinde istatistiksel olarak anlamlı bir farka rastlanmamıştır. Ortalama değerlerin birbirine çok yakın olduğu görülmüştür.

Tablo 2. Serbest zaman motivasyon değerlerinin sporcu lisansı değişkenine göre dağılımları

\begin{tabular}{lllcccc}
\hline & Lisans & $\mathbf{N}$ & Ort. $(\overline{\mathbf{x}})$ & $\mathbf{S .}$ & $\mathbf{t}$ & p \\
\hline \multirow{2}{*}{ Bilmek ve Başarmak } & Evet & 74 & 4,01 &, 63 &, 856 & \multirow{2}{*}{, 393} \\
& Hayır & 217 & 3,94 &, 58 & & \\
Uyaran Yaşama & Evet & 74 & 3,92 &, 80 &, 203 &, 840 \\
& Hayır & 217 & 3,90 &, 81 & & \\
\multirow{2}{*}{ Özdeşim/İçe Atım } & Evet & 74 & 3,85 &, 53 &,- 032 &, 975 \\
\multirow{2}{*}{ Dişsal Düzenleme } & Hayır & 217 & 3,86 &, 51 & & \\
\multirow{2}{*}{ Motivasyonsuzluk } & Evet & 74 & 2,70 &, 75 &,- 347 & \multirow{2}{*}{, 729} \\
& Hayır & 217 & 2,73 &, 73 & & \multirow{2}{*}{, 925} \\
\hline & Evet & 74 & 2,35 &, 87 &, 094 & \\
\hline
\end{tabular}


Gürer, B. (2021). Covid-19 pandemi sürecinde spor yapan bireylerin serbest zaman motivasyonlarının incelenmesi. Spor Bilimleri Araştırmaları Dergisi, 6(1), 24-35.

Serbest zaman motivasyon değerleri katılımcıların sporcu lisansının olup olmamasına göre incelendiğinde istatistiksel olarak anlamlı bir farka rastlanmamıştır. Katılımcıların çoğunun $(\mathrm{N}=217)$ sporcu lisansına sahip olmadığı görülmüştür.

Tablo 3. Serbest zaman motivasyon değerlerinin yaş değişkenine göre dağılımları

\begin{tabular}{|c|c|c|c|c|c|c|}
\hline & Yaş & $\mathbf{N}$ & Ort. ( $\overline{\mathbf{x}})$ & S. & $\mathbf{F}$ & $\mathbf{p}$ \\
\hline \multirow{5}{*}{ Bilmek ve Başarmak } & $18-21$ yaş & 28 & 3,86 & ,66 & \multirow{5}{*}{, 675} & \multirow{5}{*}{,610 } \\
\hline & $22-25$ yaş & 87 & 3,96 & ,58 & & \\
\hline & $26-30$ yaş & 104 & 3,99 &, 51 & & \\
\hline & $31-35$ yaş & 35 & 3,86 & 80 & & \\
\hline & 36 yaş ve üstü & 37 & 4,03 &, 56 & & \\
\hline \multirow{5}{*}{ Uyaran Yaşama } & 18-21 yaş & 28 & 4,05 & ,75 & \multirow{5}{*}{, 850} & \multirow{5}{*}{,494 } \\
\hline & $22-25$ yaş & 87 & 3,99 &, 75 & & \\
\hline & $26-30$ yaş & 104 & 3,85 &, 87 & & \\
\hline & $31-35$ yaş & 35 & 3,77 &, 70 & & \\
\hline & 36 yaş ve üstü & 37 & 3,87 & 87 & & \\
\hline \multirow{5}{*}{ Özdeşim/İçe Atım } & $18-21$ yaş & 28 & 3,66 & ,64 & \multirow{5}{*}{1,404} & \multirow{5}{*}{,233 } \\
\hline & $22-25$ yaş & 87 & 3,86 &, 51 & & \\
\hline & $26-30$ yaş & 104 & 3,88 & ,49 & & \\
\hline & $31-35$ yaş & 35 & 3,84 &, 51 & & \\
\hline & 36 yaş ve üstü & 37 & 3,96 & ,48 & & \\
\hline \multirow{5}{*}{ Dişsal Düzenleme } & $18-21$ yaş & 28 & 2,77 & ,72 & \multirow{5}{*}{, 279} & \multirow{5}{*}{,891 } \\
\hline & $22-25$ yaş & 87 & 2,72 & ,73 & & \\
\hline & $26-30$ yaş & 104 & 2,72 & ,72 & & \\
\hline & $31-35$ yaş & 35 & 2,63 & ,78 & & \\
\hline & 36 yaş ve üstü & 37 & 2,81 &, 78 & & \\
\hline \multirow{5}{*}{ Motivasyonsuzluk } & 18-21 yaş & 28 & 2,58 & ,84 & \multirow{5}{*}{, 828} & \multirow{5}{*}{, 508} \\
\hline & $22-25$ yaş & 87 & 2,41 & ,99 & & \\
\hline & $26-30$ yaş & 104 & 2,25 & ,89 & & \\
\hline & $31-35$ yaş & 35 & 2,31 & ,92 & & \\
\hline & 36 yaş ve üstü & 37 & 2,31 & ,95 & & \\
\hline
\end{tabular}

Serbest zaman motivasyonları değerleri yaş değişkenine göre incelendiğinde istatistiksel olarak anlamlı bir farka rastlanmamıştır. Katılımcıların çoğunun 22-30 yaş aralığında olduğu görülmüştür.

Tablo 4. Serbest zaman motivasyon değerlerinin eğitim durumu değişkenine göre dağılımları

\begin{tabular}{|c|c|c|c|c|c|c|c|}
\hline & Durumu & $\mathbf{N}$ & Ort. $(\overline{\mathbf{x}})$ & S. & $\mathbf{F}$ & $\mathbf{p}$ & Fark \\
\hline \multirow{4}{*}{ Bilmek ve Başarmak } & İlköğretim & 15 & 3,78 & ,90 & \multirow{4}{*}{1,538} & \multirow{4}{*}{,205 } & \\
\hline & Lise & 71 & 3,90 &, 53 & & & \\
\hline & Lisans & 187 & 4,01 &, 58 & & & \\
\hline & Lisansüstü & 18 & 3,80 &, 57 & & & \\
\hline \multirow{4}{*}{ Uyaran Yaşama } & İlköğretim & 15 & 3,95 & ,87 & \multirow{4}{*}{,658 } & \multirow{4}{*}{, 578} & \\
\hline & Lise & 71 & 4,00 &, 66 & & & \\
\hline & Lisans & 187 & 3,88 &, 83 & & & \\
\hline & Lisansüstü & 18 & 3,75 & 1,02 & & & \\
\hline \multirow{4}{*}{ Özdeşim/İçe Atım } & İlköğretim & 15 & 3,55 & ,65 & \multirow{4}{*}{2,158} & \multirow{4}{*}{,093 } & \\
\hline & Lise & 71 & 3,83 & 46 & & & \\
\hline & Lisans & 187 & 3,89 &, 52 & & & \\
\hline & Lisansüstü & 18 & 3,83 &, 54 & & & \\
\hline \multirow{4}{*}{ Dışsal Düzenleme } & İlköğretim & 15 & 2,83 & 71 & \multirow{4}{*}{, 255} & \multirow{4}{*}{, 858} & \\
\hline & Lise & 71 & 2,73 & ,71 & & & \\
\hline & Lisans & 187 & 2,73 & ,75 & & & \\
\hline & Lisansüstü & 18 & 2,61 & 76 & & & \\
\hline \multirow{4}{*}{ Motivasyonsuzluk } & İlköğretim & 15 & 2,77 & ,75 & \multirow{4}{*}{3,716} & \multirow{4}{*}{, $012 *$} & \multirow{4}{*}{$\begin{array}{c}1-3,2-3 \\
4-3\end{array}$} \\
\hline & Lise & 71 & 2,49 & ,95 & & & \\
\hline & Lisans & 187 & 2,22 & ,91 & & & \\
\hline & Lisansüstü & 18 & 2,70 & 1,00 & & & \\
\hline
\end{tabular}


Serbest zaman motivasyonları değerleri eğitim durumu değişkenine göre incelendiğinde motivasyonsuzluk alt boyutunda istatistiksel olarak anlamlı bir farka bulunmuştur $(\mathrm{p}<, 05)$. Lisans eğitimine sahip sporcuların motivasyon puanlarının diğer gruplardan daha düşük olduğu görülmüştür.

Tablo 5. Serbest zaman motivasyon değerlerinin spor branşı değişkenine göre dağglımları

\begin{tabular}{|c|c|c|c|c|c|c|}
\hline & Yapılan Spor & $\mathbf{N}$ & Ort. $(\overline{\mathbf{x}})$ & S. & $\mathbf{F}$ & $\mathbf{p}$ \\
\hline \multirow{8}{*}{ Bilmek ve Başarmak } & Kampçılık & 55 & 4,06 & ,56 & \multirow{8}{*}{1,416} & \multirow{8}{*}{,198 } \\
\hline & Doğa Yürüyüşü & 61 & 3,95 &, 52 & & \\
\hline & Bisiklet & 50 & 4,02 &, 59 & & \\
\hline & Koşu & 26 & 3,86 &, 47 & & \\
\hline & Dağcılık & 34 & 3,86 & 61 & & \\
\hline & Yamaç Paraşütü & 22 & 3,80 & ,66 & & \\
\hline & Tenis & 31 & 3,90 &, 80 & & \\
\hline & Diğger & 12 & 4,31 &, 41 & & \\
\hline \multirow{8}{*}{ Uyaran Yaşama } & Kampçılık & 55 & 3,75 & ,93 & \multirow{8}{*}{2,037} & \multirow{8}{*}{, 051} \\
\hline & Doğa Yürüyüşü & 61 & 4,06 &, 66 & & \\
\hline & Bisiklet & 50 & 4,03 &, 67 & & \\
\hline & Koşu & 26 & 3,80 & ,93 & & \\
\hline & Dağcılık & 34 & 3,60 &, 88 & & \\
\hline & Yamaç Paraşütü & 22 & 3,77 & 1,06 & & \\
\hline & Tenis & 31 & 4,10 &, 61 & & \\
\hline & Diğger & 12 & 4,13 &, 54 & & \\
\hline \multirow{8}{*}{ Özdeşim/İçe Atım } & Kampçılık & 55 & 3,86 &, 45 & \multirow{8}{*}{1,207} & \multirow{8}{*}{,299 } \\
\hline & Doğa Yürüyüşü & 61 & 3,94 & ,43 & & \\
\hline & Bisiklet & 50 & 3,73 &, 55 & & \\
\hline & Koşu & 26 & 3,89 &, 65 & & \\
\hline & Dağcılık & 34 & 3,72 & ,68 & & \\
\hline & Yamaç Paraşütü & 22 & 3,96 &, 41 & & \\
\hline & Tenis & 31 & 3,91 & ,49 & & \\
\hline & Diğger & 12 & 3,94 &, 32 & & \\
\hline \multirow{8}{*}{ Dişsal Düzenleme } & Kampçılık & 55 & 2,82 &, 73 & \multirow{8}{*}{1,701} & \multirow{8}{*}{, 108} \\
\hline & Doğa Yürüyüşü & 61 & 2,54 &, 77 & & \\
\hline & Bisiklet & 50 & 2,73 &, 65 & & \\
\hline & Koşu & 26 & 2,88 &, 81 & & \\
\hline & Dağcılık & 34 & 2,93 & ,66 & & \\
\hline & Yamaç Paraşütü & 22 & 2,71 & ,99 & & \\
\hline & Tenis & 31 & 2,74 &, 52 & & \\
\hline & Diğger & 12 & 2,35 &, 68 & & \\
\hline \multirow{8}{*}{ Motivasyonsuzluk } & Kampçılık & 55 & 2,26 & ,93 & \multirow{8}{*}{1,089} & \multirow{8}{*}{, 370} \\
\hline & Doğa Yürüyüşü & 61 & 2,34 & ,96 & & \\
\hline & Bisiklet & 50 & 2,26 &, 83 & & \\
\hline & Koşu & 26 & 2,50 & 1,02 & & \\
\hline & Dağcılık & 34 & 2,50 &, 97 & & \\
\hline & Yamaç Paraşütü & 22 & 2,62 & 1,06 & & \\
\hline & Tenis & 31 & 2,32 & ,90 & & \\
\hline & Diğger & 12 & 1,86 &, 57 & & \\
\hline
\end{tabular}

Serbest zaman motivasyon değerleri, yapılan spor değişkenine göre incelendiğinde istatistiksel olarak anlamlı bir farka rastlanmamıştır. Katılımcıların kampçılık, doğa yürüyüşü, dağcılık ve yamaç paraşütü gibi doğa sporlarına eğilimi olduğu görülmüştür. Bununla birlikte ortalama puanların birbirine yakın değerler olduğu sonucu ortaya çıkmıştır. 
Gürer, B. (2021). Covid-19 pandemi sürecinde spor yapan bireylerin serbest zaman motivasyonlarının incelenmesi. Spor Bilimleri Araştırmalarl Dergisi, 6(1), 24-35.

\section{TARTIŞMA VE SONUÇ}

Araştırmada öncelikli olarak Covid-19 pandemi sürecinde rekreatif olarak spor yapan bireylerin serbest zaman motivasyonları incelenmiş olup daha sonra bu süreçte hangi sporlara yöneldiklerinin incelenmesi amaçlanmıştır. Büyük kısıtlamaların olduğu bu süreçte ülkemizdeki tüm bireyler serbest zamanlarını harcadıkları birçok ortamdan ve spor alanlarından oldukça uzun süre ayrı kalmış durumdadır. Covid-19 salgını sırasında alışveriş merkezleri, büyük mağazalar, oteller, restoranlar, spor merkezleri ve spor salonları çok az ziyaretçiye sahip olmuş; online alışveriş ve yemek dağıtım hizmetleri eskisinden çok daha yoğun bir hale dönüşmüştür (Tsai, 2020).

Serbest zaman motivasyon değerlerinin cinsiyet değişkenine göre dağılımları incelendiğinde (Tablo 1) istatistiksel bir fark bulunmamakla birlikte ortalamaların birbirine çok yakın olduğu görülmüştür. $\mathrm{Bu}$ sonuca göre cinsiyet fark etmeksizin Covid-19 pandemi süreci her iki cinsiyette aynı etkiyi göstermiştir. Moccia'ya (2000) göre cinsiyet, serbest zaman etkinliklerine katılımda önemli bir rol oynamaktadır. Araştırmada, en düşük ortalamaların motivasyonsuzluk alt boyutunda olduğu görülmüştür. Bu durum Covid-19 pandemi sürecinin belirsizliklerinin serbest zaman olan etkisi olarak açıklanabilir. Gürer'in (2020) oryantiring sporcuları üzerine yaptığı araştırmasında cinsiyete göre serbest zaman motivasyonlarında benzer bir sonuç elde etmiştir. Türker, Ölçer ve Aydın (2016) da cinsiyete göre serbest zaman faaliyetleri arasında bir fark bulamamıştır. Buna rağmen bazı araştırmalar, erkeklerin serbest zamanlarında kadınlardan daha aktif olduğunu ileri sürmektedir (Azevedo vd., 2007; Burton ve Turrell, 2000; Gomes, Siqueira ve Sichieri, 2001; Monteiro vd., 2003). Araştırma sonucunda fark çıkmaması normal olarak değerlendirilebilir. Bunun sebebini Covid-19 pandemisinin her iki cinsiyet grubuna da aynı düzeyde olumsuz etki etmiş olması şeklide açıklanabilir. Azevedo vd., (2007) göre erkekler ve kadınlar farklı fiziksel aktivite seviyelerine sahiptir ve aktivite seviyeleriyle ilişkili değişkenler cinsiyetler arasında tutarlı değildir.

Serbest zaman motivasyon değerlerinin sporcu lisansı değişkenine göre dağılımları incelendiğinde (Tablo 2) istatistiksel bir fark bulunamamıştır. Katılımcıların çoğunun (n=217) sporcu lisansına sahip olmadığı görülmüştür. Bu sonuç yapılan sporların daha çok rekreasyonel amaçlı olduğu ile ilişkilendirilebilir. Gürer'in (2020) oryantiring sporcuları üzerine yaptığ1 araştırmasında da sporcu lisansına göre serbest zaman motivasyonlarında bir fark bulunamamıştır. Kangalgil, Hünük ve Demirhan (2006)'da öğrenciler üzerine yapmış olduğu araştırmasında sporcu lisansı olmayan öğrencilerin sayısının daha fazla olduğu sonucuna ulaşmıştır. Covid-19 pandemi sürecinde sporcu lisansı üzerine yapılan araştırma sayısının az olması literatürü kısıtlamakla birlikte genel olarak rekreatif olarak spora katılanların çoğunun sporcu lisansına sahip olmadığı görülmektedir. Elde ettiğimiz bu sonuç ileride yapılacak olan araştırmalarda tartışılabilir. Tüm alt boyutlarda ortalamaların birbirine çok yakın olması serbest zaman etkinliğinde bir lisansa sahip olmanın motivasyona çok etki etmediğini düşündürmektedir. Mevcut araştırma sonuçları serbest zaman etkinliğine katılanların lisanslı bir spor dalını yapmayı daha az tercih ettiği şeklinde de yorumlanabilir.

Serbest zaman motivasyon değerlerinin yaş değişkeni dağılımlarına göre (Tablo 3) istatistiksel bir fark bulunmamıştır. Diğer değişkenlerde olduğu gibi ortalamalar birbirine oldukça yakındır. Serbest zaman etkinliği olarak 26-30 yaş grubunun daha aktif olduğu görülmüştür $(n=104)$. Okulların kapalı olması ve eğitimin uzaktan yapılması nedeni ile 18-30 yaş aralığındaki bireylerin daha çok serbest zaman etkinliğine katıldığı görülmüştür. İstatistiksel bir fark olmasa 
da uyaran yaşama alt boyutu hariç genel olarak yaş arttıkça serbest zaman motivasyon puanlarının yükseldiği söylenebilir. Francken ve Van Raaij (1981) yaşlı ve iyimser bir bakış açısına sahip kişiler için serbest zaman memnuniyetinin daha yüksek olduğu sonucuna varmıştır. Ayrıca serbest zaman memnuniyeti düşük olan kişiler daha gençtir ve kötümser bir görünüme sahiptir (Francken ve Van Raaij, 1981). Bu durum gençlerin işsizlik, çalışma isteğinin olmaması ve Covid-19 pandemi sürecinin getirmiş olduğu yoğun ekonomik ve sosyal problemlerle de ilişkili olabilir. Azevedo vd., (2007) erkeklerde yaş ve hareketsizlik arasında pozitif bir cevap tespit etmiş, kadınlar için ise bir oran bulamamıştır. Türker vd., (2016) göre olgun yaştaki bireylerin iş ve aile sorumluluklarının fazla olması serbest zaman faaliyetlerine katılmalarındaki en önemli engeller olabilmektedir. Bu sebeple yaşın serbest zaman etkinliklerine katılımda öncül bir etken olduğu söylenebilir.

Serbest zaman motivasyon değerlerinin eğitim durumu değişkenine göre dağılımları incelendiğinde (Tablo 4) motivasyonsuzluk alt boyutundan istatistiksel olarak anlamlı bir fark bulunmuştur $(\mathrm{p}<, 05)$. Fark1 yaratan etkenin lisans eğitimine sahip bireylerden kaynaklandığı görülmektedir $(\bar{x}=2,22)$. Motivasyonsuzluk alt boyutunda en düşük ortalamaya lisans mezunları sahiptir. Bu durum özellikle Covid-19 pandemi sürecinde hızla artan ekonomik krizin lisans mezunları tarafından çok ciddiye almaması alakalı olabilir. Lisans mezunları serbest zamanlarında katıldıkları etkinliklerden daha çok keyif almaktadır. Benzer şekilde Gürer (2020), araştırmasında deneyimi daha az olan genç sporcuların motivasyonsuzluk yaşadığı sonucuna ulaşmıştır. Motivasyonsuzluk puanları en yüksek olan grup ise ilköğretim mezunlarıdır. Bu sonuç eğitim durumlarından kaynaklı olarak Covid-19 pandemi sürecinin olumsuz etkilerinin bu grup tarafından daha çok hissedildiği şeklinde yorumlanabilir. Gökçe (2008), eğitim seviyesi düşük bireylere serbest zaman etkinlikleri düzenlerken, kişilerin kendilerini geliştirmesini sağlayacak etkinlikler planlanması gerektiğine değinmiştir. Türker, Ölçer ve Aydın (2016), yerel halkın serbest zaman değerlendirme alışkanlıklarını inceledikleri araştırmalarında eğitim durumu gibi demografik değişkenlerinin serbest zaman faaliyetlerine katılmada anlamlı bir farklılık yaratmadığı sonucuna ulaşılmıştır. Çuhadar, Yusuf, Demirel ve Demirel (2019) bireyleri rekreasyonel amaçlı egzersize motive eden faktörleri inceledikleri araştırmalarında eğitim durumuna göre daha çok sağlı amaçlı bir katılım gösterildiği sonucuna ulaşmıştır. Tüm bu sonuçlar değerlendirildiğinde eğitim seviyesi serbest zaman katılımda farklılık gösteren bir değişken olarak gözükmektedir.

Serbest zaman motivasyon değerlerinin yapılan spor branşı değişkenine göre dağılımlarına incelendiğinde (Tablo 5) istatistiksel olarak anlamlı bir fark bulunmamıştır. Bununla birlikte katılımcıların daha çok hangi tür serbest zaman etkinlikleri tespit edilmeye çalışılmıştır. Araştırmada doğa sporlarına ve bireysel sporlara yönelim olduğu görülmüştür. Kapalı ortamlarda bir araya gelmenin olumsuz etkileri düşünüldügünde Covid-19 pandemi sürecinde açık alandaki rekreasyon faaliyetleriyle birlikte doğa yapılan etkinliklere katılım fazladır. Yapılan araştırmalarda, düzenli fiziksel aktivite sürekli olarak düşük ölüm riski ile ilişkilendirilmiştir (Paffenbarger, Hyde, Wing ve Hsieh, 1986). Bu sonuçlara göre serbest zamanlarda düzenli spor yapmanın sağlıklı yaşam için önemli etkisi olduğu söylenebilir. Kalabalık ortamlara girmekten kaçınmak, mümkün olduğunca az kişi ile temas halinde olmak ve daha izole etkinlikler yapmak adına dağcılık, kampçılık, doğa yürüyüşü ve yamaç paraşütü gibi doğa sporlarına yönelim olduğu mevcut araştırma ile ortaya konmuştur. Serbest zamanlarda doğa sporları yapmak tercih edilen bir etkinliktir. Doğada yapılan serbest zaman etkinlikleri katılan bireylere istediği imkanları sunmaktadır. Serbest zamanlarda doğa sporu 
yapmak bireylere, yüksek özgürlük hissi yaşatan, mutluluk veren, sosyalleştiren, kendi seviyelerine göre faaliyet imkanı yaratan, amaçlandığı tarzda bir etkinlik sunan ve serbest zamanları en sağlıklı şekilde kullandıran bir faaliyet şeklinde ortaya çıkmaktadır (Gürer ve Caymaz, 2019). Güneydoğu Anadolu bölgesinde doğa sporları kulüpleri bulunmakta ve doğa yürüyüşü, dağcılık gibi etkinliklerin yapıldığı görülmektedir (Gürer, Alıncak ve Öcalan, 2016). Bir serbest zaman etkinliği olarak doğa sporları Covid-19 pandemi sürecinde yapılabilir bir seviyede gözükmekte ve açık alanda yapılmasından dolayı avantaj sağlayabilmektedir. Bir çalışma, yeşil bir çevrede yaşamanın, stres seviyeleri ve fiziksel aktivite miktarı gibi sağlık göstergeleriyle pozitif olarak ilişkili olduğunu ortaya koymuştur (De Vries, Verheij, Groenewegen ve Spreeuwenberg, 2003). Doğa sporlarının ise olumlu etkileri yapılan çalışmalarda ortaya konmuştur (Godbey, 2009; Gürer, 2015; Gürer ve Kılınç, 2019; McKenzie, 2000).

Sonuç olarak, Covid-19 pandemi sürecinde serbest zaman motivasyonuna etki edecek öncül bir fark ortaya çıkmamıştır. Araştırmaya katılım sayısının çok fazla olmaması sonuçları etkilemiş olabilir. Net bir sonuç olarak, lisans mezunlarının serbest zaman etkinliklerindeki motivasyonları daha iyi seviyededir. Bununla birlikte tüm değişkenlerde en düşük ortalamaların dışsal düzenleme ve motivasyonsuzluk alt boyutlarında olduğu görülmüştür. Serbest zamanlarında bir etkinliğe katılan bireylerin daha çok doğada yapılan etkinlikler ile bireysel sporları tercih ettiği görülmüştür. Doğada yapılan etkinliklere yönelim olması bireylerin açık alanı daha güvenli bulmaları ile ilişkilendirilebilir. Bununla birlikte doğaya çıkan insan sayısının artması bir yandan da çevre kirliliği sorunu oluşturabilir. Covid-19 pandemi sürecinde kurallara uygun olarak doğada ve açık alanda yapılan sporların arttırılması sağlık açısından önerilmektedir. Daha fazla örneklem sayısı ve farklı bölgelerde yapılacak çalışmalar ile elde edilen sonuçlarımız tartışılabilir.

Çıkar Çatışması: Çalışma kapsamında herhangi bir kişisel ve finansal çıkar çatışması bulunmamaktadir.

Araştırmacıların Katkı Oranı Beyanı: Araştırmanın dizaynı, verilerin toplanması ve analizi makalenin hazırlanmas1, BG.

\section{Etik Kurul İzni ile ilgili Bilgiler}

Kurul Adı: Gaziantep Üniversitesi Sosyal ve Beşeri Bilimler Etik Kurulu

Tarih: 27.01.2021

Sayı/Karar No: 2021/04 
Gürer, B. (2021). Covid-19 pandemi sürecinde spor yapan bireylerin serbest zaman motivasyonlarının incelenmesi. Spor Bilimleri Araştırmaları Dergisi, 6(1), 24-35.

\section{KAYNAKLAR}

Azevedo, M. R., Araújo, C. L. P., Reichert, F. F., Siqueira, F. V., da Silva, M. C. \& Hallal, P. C. (2007). Gender differences in leisure-time physical activity. International Journal of Public Health, 52(1), 8-15. DOI $10.1007 / \mathrm{s} 00038-006-5062-1$

Bang, H. \& Ross, S. D. (2009). Volunteer motivation and satisfaction. Journal of Venue and Event Management, $1(1), 61-77$.

Bedford, T., Burningham, K., Cooper, G., Green, N. \& Jackson, T.D. (2011). Sustainable leisure: Escalations, constraints and implications. Resolve Working Paper Series, 12-11, 1-39.

Brooks, S. K., Webster, R. K., Smith, L. E., Woodland, L., Wessely, S., Greenberg, N. \& Rubin, G. J. (2020). The psychological impact of quarantine and how to reduce it: rapid review of the evidence. The Lancet, 395(10227), 912-920. https://doi.org/10.1016/S0140-6736(20)30460-8

Burton, N.W. \& Turrell, G. (2000). Occupation, hours worked, and leisure-time physical activity. Prev Med., 31, 673-81. https://doi.org/10.1006/pmed.2000.0763

Campbell, J. P. \& Turner, J. E. (2018). Debunking the myth of exercise-induced immune suppression: redefining the impact of exercise on immunological health across the lifespan. Frontiers in immunology, 9, 648. https://doi.org/10.3389/fimmu.2018.00648

Carriedo, A., Cecchini, J. A., Fernandez-Rio, J. \& Méndez-Giménez, A. (2020). COVID-19, Psychological Wellbeing and Physical Activity Levels in Older Adults during the Nationwide Lockdown in Spain. The American Journal of Geriatric Psychiatry, 28(11), 1146-1155. https://doi.org/10.1016/j.jagp.2020.08.007

Chelladurai, P. (2006). Human resource management in sport and recreation. Champaign, IL: Human Kinetics.

Chen, Z. Y. (2001). The study of elementary teachers' leisure participation, experience in leisure benefits, and work satisfaction in Taipei County. National Taiwan Normal University.

Çuhadar, A., Yusuf, E. R., Demirel, M. ve Demirel, D. H. (2019). Bireyleri rekreasyonel amaçli egzersize motive eden faktörlerin incelenmesi. Spormetre Beden Eğitimi ve Spor Bilimleri Dergisi, 17(3), 153-161. DOI: $10.33689 /$ spormetre.562233

De Vries, S., VerheijA, R., Groenewegen, P.P. \& Spreeuwenberg, P. (2003). Natural environments-healthy environments? An exploratory analysis of the relationship between green space and health. Environment and Planning, 35(10), 1717-1731. DOI:10.1068/a35111

Driver, B. L. (1990). The North American experience in measuring the benefits of leisure. In Proceedings National Workshop on Measurement of Recreation Benefits (pp. 1-57). Bandoora, Australia: Phillip Institute of Technology.

Ellis, G. A. \& Witt, P. A. (1986). The leisure diagnostic battery: past, present, and future. Therapeutic Recreation Journal, 20, 31-47.

Francken, D. A. \& Van Raaij, W. F. (1981). Satisfaction with leisure time activities. Journal of Leisure Research, 13(4), 337-352. https://doi.org/10.1080/00222216.1981.11969498

Gilat, R. \& Cole, B. J. (2020). COVID-19, medicine, and sports. Arthroscopy, Sports Medicine, and Rehabilitation, 2(3), e175-e176. https://doi.org/10.1016/j.asmr.2020.04.003

Godbey, G. (2009). Outdoor recreation, health, and wellness: Understanding and enhancing the relationship. Washington: Outdoor Resources Review Group. Retrieved from. Discussion Paper, 1-29.

Gomes, V.B., Siqueira, K.S. \& Sichieri, R. (2001). Physical activity in a probabilistic sample in the city of Rio de Janeiro. Cad Saude Publica 17, 969-76. https://doi.org/10.1590/S0102-311X2001000400031

Gökçe, H. (2008). Serbest zaman doyumunun yaşam doyumu ve sosyo-demografik değişkenlerle ilişkisinin incelenmesi. Yüksek Lisans Tezi, Pamukkale Üniversitesi Sağlık Bilimleri Enstitüsü, Denizli. 
Gürer, B. (2021). Covid-19 pandemi sürecinde spor yapan bireylerin serbest zaman motivasyonlarının incelenmesi. Spor Bilimleri Araştırmaları Dergisi, 6(1), 24-35.

Güngörmüş, H.A. (2012). The Study of validity and reliability of Turkish version of leisure motivation scale. Energy Education Science and Technology Part B: Social and Educational Studies, 4(3), 1209-1216.

Gürer, B. (2015). The investigation of problem-solving skill of the mountaineers in terms of demographic variables. Educational Research and Reviews, 10(11), 1496-1504. DOI: 10.5897/ERR2015.2129

Gürer, B., Alıncak, F. ve Öcalan, M. (2016). Türkiye'deki dağcılık ve doğa sporları kulüpleri ile faaliyet alanlarının incelenmesi. Gaziantep Üniversitesi Sosyal Bilimler Dergisi, 15(3), 987-1000.

Gürer, B. \& Caymaz, E. (2019). Investigation of leisure perceptions of individuals in outdoor sports. International Journal of the Sociology of Leisure, 2(3), 255-265. https://doi.org/10.1007/s41978-018-0021-y

Gürer, B. ve Kılınç, Z. (2019). Doğa sporları yapanların temel psikolojik ihtiyaçlarının zihinsel dayanıklılığa etkisi. CBÜ Beden Eğitimi ve Spor Bilimleri Dergisi, 14(2), 222-233. DOI:10.33459/cbubesbd.576242

Gürer, B. (2020). Oryantiring sporu yapan gençlerin serbest zaman motivasyonlarının incelenmesi. Journal of Social and Humanities Sciences Research, 7(62), 3373-3379. http://dx.doi.org/10.26450/jshsr.2200

Güzel, P., Yıldız, K., Esentaş, M. \& Zerengök, D. (2020). "Know-How” to spend time in home isolation during COVID-19; restrictions and recreational activities. International Journal of Psychology and Educational Studies, 7(2), 122-131. http://dx.doi.org/10.17220/ijpes.2020.02.011

Hammami, A., Harrabi, B., Mohr, M. \& Krustrup, P. (2020). Physical activity and coronavirus disease 2019 (COVID-19): specific recommendations for home-based physical training. Managing Sport and Leisure, 1-6. https://doi.org/10.1080/23750472.2020.1757494

Hegde, S. M. \& Solomon, S. D. (2015). Influence of physical activity on hypertension and cardiac structure and function. Current hypertension reports, 17(10), 1-8. DOI 10.1007/s11906-015-0588-3

Iso-Ahola, S.E. (1980). Social psychological perspective on leisure and recreation. Springfield, IL: Charles C. Thomas.

Iso-Ahola, S. E. \& Wessinger, E. (1984). Leisure and well-being: is there a connection? Parks and Recreation, $19,40-44$.

Kangalgil, M., Hünük, D. ve Demirhan, G. (2006). İlköğretim, lise ve üniversite öğrencilerinin beden eğitimi ve spora ilişkin tutumlarının karşılaştırılması. Spor Bilimleri Dergisi, 17(2), 48-57.

Kao, C. H. (1995). A three-factor model of leisure benefits. Journal of outdoor recreation study, 8(1), 67-78.

Kim, E. (2018). A systematic review of motivation of sport event volunteers. World Leisure Journal, 60(4), 306329. https://doi.org/10.1080/16078055.2017.1373696

Kluge, H. H. P. (2020). Statement-Older people are at highest risk from COVID-19, but all must act to prevent community spread. Retrieved from World Health Organization website: http://www. euro. who. $\mathrm{int/en/health-topics/health-emergencies/coronavirus-covid-19/statements/statement-older-people-are-at-}$ highest-risk-from-covid-19,-but-all-must-act-to-prevent-community-spread.

McKenzie, M. D. (2000). How are adventure education program outcomes achieved?: A review of the literature. Journal of Outdoor and Environmental Education, 5(1), 19-27.

MacKenzie, S. H. \& Goodnow, J. (2020). Adventure in the age of COVID-19: Embracing microadventures and locavism in a post-pandemic world. Leisure Sciences, 43,1-2, 62-69. https://doi.org/10.1080/01490400.2020.1773984

Moccia, F. D. (2000). Planning Time: An emergent european practice. European Planning Studies, 8(3), 367-376.

Monteiro, C.A., Conde, W.L., Matsudo, S.M., Matsudo, V.R., Bonsenor, I.M. \& Lotufo, P.A. (2003). A descriptive epidemiology of leisure-time physical activity in Brazil, 1996-1997. Rev Panam Salud Publica 14, 246-54.

Mutlu, İ. (2008). Egzersiz yapan kişilerin boş zamanlarına yönelik tutumları üzerine bir araştırma (Kayseri İli Örneği). Yüksek Lisans Tezi, Niğde Üniversitesi, Niğde. 
Gürer, B. (2021). Covid-19 pandemi sürecinde spor yapan bireylerin serbest zaman motivasyonlarının incelenmesi. Spor Bilimleri Araştırmaları Dergisi, 6(1), 24-35.

Paffenbarger Jr, R. S., Hyde, R., Wing, A. L. \& Hsieh, C. C. (1986). Physical activity, all-cause mortality, and longevity of college alumni. New England journal of medicine, 314(10), 605-613.

Pelletier, L.G., Vallerand, R.J., Blais, M.R. \& Brière, N.M. (1991). Leisure Motivation Scale (LMS-28). http://www.er.uqam.ca/nobel/r26710/LRCS/echelles_en.htm.

Sivan, A. (2020). Reflection on leisure during COVID-19. World Leisure Journal, 62(4), 296-299. https://doi.org/10.1080/16078055.2020.1825260

Soyer, F., Yıldız, N. O., Harmandar Demirel, D., Serdar, E., Demirel, M., Ayhan, C. ve Demirhan, Ö. (2017). Üniversite öğrencilerinin rekreatif etkinliklere katılımlarına engel teşkil eden faktörler ile katılımcıların yaşam doyumları arasındaki ilişkinin incelenmesi. Journal of Human Sciences, 14(2), 2035-2046. doi:10.14687/jhs.v14i2.4647

Thomson, M.D., Spence, J.C., Raine, K. \& Laing, L. (2008). The Association of television viewing with snacking behavior and body weight of young adults. American Journal of Health Promotion 22(5), 329-35.

Tsai, C. T. L. (2020). COVID-19 reflections. World Leisure Journal, 62(4), 336-338. https://doi.org/10.1080/16078055.2020.1825253.

Türker, N., Ölçer, H. ve Aydın, A. (2016). Yerel Halkın serbest zaman değerlendirme alışkanlıkları: Safranbolu Örneği. Karabük Üniversitesi Sosyal Bilimler Enstitüsü Dergisi, 6(1), 49-62.

Woods, J., Hutchinson, N. T., Powers, S. K., Roberts, W. O., Gomez-Cabrera, M. C., Radak, Z., ... \& CoelhoJúnior, H. J. (2020). The COVID-19 pandemic and physical activity. Sports Medicine and Health Science 2, 55-64. https://doi.org/10.1016/j.smhs.2020.05.006

World Health Organization. (2021). Coronavirus Disease (COVID-19) Dashboard. Erişim tarihi: 08.04.2021 https://covid19.who.int/.

Bu eser Creative Commons Atıf-GayriTicari 4.0 Uluslararası Lisansı ile lisanslanmıştır. 